\title{
The Ecological Effect of Village and Biopsychosocial Factors Affecting the Quality of Life of Elderly in Surakarta, Central Java
}

\author{
Dwi Tour Kumalasari'), Bhisma Murti'), Vitri Widyaningsih²) \\ 1)Masters Program in Public Health, Universitas Sebelas Maret \\ ${ }^{2)}$ Faculty of Medicine, Universitas Sebelas Maret
}

\section{ABSTRACT}

Background: Along with the increasing number of the elderly, there are many problems experienced by the elderly including not educated, do not get access to health, do not have old age insurance, and do not have social support from family or friends to care for them. Elderly people had high vulnerable risk to experience various psychological and physical problems. This study aimed to analyze the influence of biopsychosocial and contextual village social capital in the elderly. Subjects and Method: This was a cross sectional study conducted in Surakarta, Central Java, in December 2019. A sample of 200 elderly was selected by simple random sampling at the individual level and stratified simple random sampling at the village level. The dependent variable was quality of life. The independent variables were education, income, marital status, BMI, physical activity, locus of control, family support, social support, and social capital. The data was collected by questionnaire. The data were analyzed by a multiple logistic regression run on Stata 13

Results: Quality of life improved by education zelementary school $(\mathrm{b}=2.72 ; 95 \% \mathrm{CI}=0.17$ to 5.26; $\mathrm{p}=0.036$ ), income $\geq \operatorname{Rp} 1,800,000(\mathrm{~b}=$ 2.90; $95 \% \mathrm{CI}=0.71$ to $5.10 ; \mathrm{p}=0.010$ ), married $(\mathrm{b}=2.37 ; 95 \% \mathrm{CI}=0.13$ to $4.62 ; \mathrm{p}=0.038), \mathrm{BMI}$ $(b=4.01 ; 95 \% \mathrm{CI}=1.50$ to $6.53 ; \mathrm{p}=0.002)$, good physical activity $(b=2.26 ; 95 \% \mathrm{CI}=0.33$ to 4.20 ; $\mathrm{p}=0.022)$, internal locus of control $(b=2.69$; $95 \% \mathrm{CI}=0.41$ to $4.98 ; \mathrm{p}=0.021$ ), strong family support $(b=2.88 ; 95 \% \mathrm{CI}=0.48$ to $5.28 ; \mathrm{p}=$ o.018), strong social support ( $\mathrm{b}=2.28 ; 95 \% \mathrm{CI}=$ 0.02 to $4.55 ; \mathrm{p}=0.048$ ), and good social capital $(b=2.30 ; 95 \% \mathrm{CI}=0.11$ to $4.51 ; \mathrm{p}=0.040)$. Village had a contextual effect on the quality of life of elderly with intra-class correlation (ICC) $=40.52 \%$. Conclusion: Quality of life improves by education $\geq$ elementary school, high income, married, BMI, good physical activity, internal locus of control, strong family support, strong social support, and good social capital. Village has a contextual effect on the quality of life of elderly.

Keywords: quality of life, biopsychosocial, elderly, multilevel analysis

\section{Correspondence:}

Dwi Tour Kumalasari. Masters Program in Public Health, Universitas Sebelas Maret, Jl. Ir. Sutami 36A, Surakarta 57126, Central Java. Email: kumalasari.azzahra@gmail.com. Mobile: +6281216417536.

\section{Cite this as:}

Kumalasari DT, Murti B, Widyaningsih V (2020). The Ecological Effect of Village and Biopsychosocial Factors Affecting The Quality of Life of Elderly in Surakarta, Central Java. J Epidemiol Public Healt. 5(1): 31-44. https://doi.org/10.26911/jepublichealth.2020.05.01.04 


\section{BACKGROUND}

World population aged 60 years or more has reached 962 million in 2017, this number has increased very high compared to 1980 . The elderly population is expected to be twice as many in 2050 to reach 2.1 billion (United Nation, 2017). The number of elderly people in Indonesia according to the Central Statistics Agency (BPS) (2018) over a period of almost 50 years (1971-2018) has roughly doubled. In 2018, the percentage of the elderly will reach 9.27 percent or around 24.49 million people. The percentage of elderly people in Indonesia is dominated by young elderly (age group 60-69 years) with a percentage reaching 63.39 percent, the rest are middle aged people (age group 70-79 years)

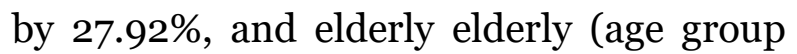
$80+$ ) amounting to 8.69 percent (Silviliyana et al., 2018).

The large number of elderly population in Indonesia in the future has both positive and negative impacts. Positive impact, if the elderly population is in a healthy, active and productive state. On the other hand, the large number of the elderly population becomes a burden if the elderly have problems in declining health resulting in an increase in the cost of health services, a decrease in income / income, an increase in disability, the absence of social and environmental support that is not friendly to the elderly population (Ministry of Health, 2017).

To improve the quality of life of the elderly refers to the active aging concept of the World Health Organization (WHO), which is the aging process that remains physically, socially and mentally healthy so that it remains prosperous throughout life and continues to participate in order to improve the quality of life as a member of the community, efforts are needed by involving various parties, especially the active role of the elderly (Setiyorini et al., 2018).

The role of social capital in community health empowerment includes mutual trust between families and communities, cooperation between community members, leaders and health workers, mutual assistance, mutual social norms, mutual relations, kinship, friendship, and friendship as well as the existence of a network of organizations society (Sulaeman et al., 2015).

Support of elderly families in urban areas is generally very high depending on the health status of the elderly. This can be seen in extended families consisting of fathers, mothers, grandmothers, grandfathers, siblings, and others in one house. In urban Surakarta (Solo Raya) the elderly are still often found shopping at the Super Market along with their grandchildren and children (Diffah Hanim, 2004).

The elderly in Indonesia usually continue to do activities with peers through social gathering, recitation and sports activities. At the meeting of the elderly (aged 60-70 years), some of them were still able to do business in catering, clothing, shoes and sandals (clothing and food). This shows that the elderly will be more excited if they have productive activities so they can buy something for their grandchildren. The elderly as micro business actors from the offered credit of Rp. 5 million per business unit showed good progress. The distribution of funding is a form of empowering the elderly who are members of the social gathering, and recitation in urban areas (Hanim and Agustina, 2007).

The higher level of education of a person is expected to be better health behavior. This was studied by Muckenhuber et al. (2014) in Austria in the elderly more than 65 years old using baseline data from micro census in the country which obtained the result that the elderly with higher education had significantly better self-health. A study by Li et al. (2014) found that education (bachelor level or higher) is one of the variables 
that influence the management of personal health in the elderly.

Study on the quality of life of the elderly in various parts of the world began to do a lot, but there is still little studies that links with social capital. Based on this, it is necessary to conduct study on the effect of bio psychosocial and contextual village social capital on the quality of older life in an effort to improve the quality of life of the elderly so that they can become members of the community who are able to participate in national development and not become a burden on families, communities, and country.

\section{SUBJECTS AND METHOD}

\section{Study Design}

This was an analytic observational study with a cross sectional design. The study was conducted in Surakarta, Central Java, in December 2019.

\section{Population and Sample}

The study population was all elderly living in Surakarta City. A sample of 200 elderly was selected by simple random sampling.

\section{Study Variables}

The dependent variable was quality of life. The independent variables were education, income, marital status, body mass index (BMI), physical activity, locus of control, family support, social support, and social capital.

\section{Operational Definition of Variables} Quality of life was a functional condition that allows them to enjoy old age happily, useful and with quality. The data were measure by WHOQOL-BREF questionnaire. The measurement scale was continuous and transformed into dichotomous, coded $\mathrm{O}=$ poor and $1=$ good.

Education is the last formal education achieved by the elderly to get a diploma, namely: the level of basic education (Elementary School and Middle School), Secondary Education Level (High School and Vocational
High School) as well as Higher Education level, namely Diploma and Bachelor Degree. The measuring instrument used was a questionnaire. The data scale is categorical with the criteria $\mathrm{O}=\langle\mathrm{SD}, 1=\geq \mathrm{SD}$.

Income is income earned by the elderly for 1 month and in the form of money. The monthly UMR of Surakarta City is Rp 1,802,700. The measuring instrument used was a questionnaire. The measurement scale was continuous and transformed into dichotomous, coded $\mathrm{o}=<\mathrm{Rp} 1,800$, ooo and $1=\geq \mathrm{Rp}$ 1,800,00o.

Marital status was the status of the study subject when conducting a study interview. The marital status here includes unmarried, widowed, and married. The measuring instrument used was a questionnaire. The data scale is categorical with the criteria $\mathrm{o}=$ single / divorced, $1=$ married.

Physical activity is a physical activity that is carried out routinely by respondents to make the body healthy, for example: elderly gymnastics, walking, and morning jogging conducted with a duration of at least 3 times a week for 30 minutes. The measuring instrument used was a questionnaire. The measurement scale was continuous and transformed into dichotomous, coded $\mathrm{o}=$ inactive, $1=$ active.

BMI is the measurement of height and weight then calculated using the formula weight in kilograms $(\mathrm{kg})$ divided by the square of height in meters $\left(\mathrm{m}^{2}\right)$. The measurement scale was continuous and transformed into dichotomous, coded $\mathrm{O}=<18.5$ or $\geq 25$ ) and $1=18.5^{-25}$.

Locus of control is an individual's beliefs about the source of behavior determinant. Control location consists of two parts, namely internal control location and external control location. The location of internal control is the way individuals believe control of events originates from their abilities, while the location of external control is the way in which 
individuals believe control of events originates from outside their abilities. The measurement scale was continuous and transformed into dichotomous, coded $\mathrm{o}=$ external, $\mathbf{1}=$ internal.

Family support is the attitude, action and various forms of support tendencies provided by family members including emotional, information, and instrumental support. The measuring instrument used questionnaire. The measurement scale was continuous and transformed into dichotomous, coded $\mathrm{O}=$ weak, $1=$ strong.

Social support is the attitude, action and various forms of tendency of support provided by members of the association (in this case the elderly posyandu/integrated service post) which includes emotional support, information, and instrumental. The measuring instrument used questionnaire. The measurement scale was continuous and transformed into dichotomous, coded $\mathrm{o}=$ weak, $1=$ strong.

Social capital is the ability of people to work together to achieve common goals in various groups and organizations. The measuring instrument was questionnaire. The measurement scale was continuous and transformed into dichotomous, coded $\mathrm{O}=$ high, $1=$ low.

\section{Data Analysis}

Univariate analysis is used to describe each dependent and independent variable. Data is grouped according to data types and entered in the frequency distribution table.

Bivariate analysis was used to determine the relationship between education, income, marital status, BMI, physical activity, locus of control, family support, social support, and social capital to quality of life measured by the chi-square test.

Multivariate analysis explains the effect of education, income, marital status, BMI, physical activity, locus of control, family support, social support, and social capital on quality of life analyzed by multiple logistic regression models. Univariate, bivariate, and multivariate analyzes were performed using the Stata 13 program.

\section{Research Ethic}

Research ethics includes consent sheets, anonymity, confidentiality, and ethical eligibility. Ethical feasibility in this study came from the Health Research Ethics Committee of Dr. Moewardi Hospital Surakarta No. 1,259 / XI / HREC / 2019.

\section{RESULTS}

\section{Sample Characteristics}

The characteristics of the sample in this study can be seen in table 1 . The characteristics of elderly were identified based on age and gender. Based on Table 1, the majority of respondents were $\geq 59$ years old (60.50\%). The majority of elderly were women (61\%).

\section{Table 1. Sample characteristics}

\begin{tabular}{|c|c|c|}
\hline \multirow{2}{*}{\multicolumn{3}{|c|}{ Frequency (n) }} \\
\hline & & \\
\hline$<59$ years & 79 & 39.50 \\
\hline$\geq 59$ years & 121 & 60.50 \\
\hline Gender & & \\
\hline Male & 78 & 39.00 \\
\hline Female & 122 & 61.00 \\
\hline
\end{tabular}

\section{Univariate Analysis}

Descriptive statistical test results of continuous data in the form of education variables, income, marital status, BMI, physical activity, locus of control, family support, social support, and social capital. 
Kumalasari et al./ The ecological effect of village and biopsychosocial factors

Based on Table 2, income shows that (mean $=14.14, \mathrm{SD}=5.44)$ with the lowest value is 7.5 and the highest is 19 . The body mass index (BMI) shows (mean $=22.27, \mathrm{SD}=$ 3.64) with the lowest value of 16.1 and the highest of 28.3. The physical activity shows that mean $=10.10$ with $\mathrm{SD}=4.13$. The locus of control shows that the value (mean $=12.14$, $\mathrm{SD}=2.93$ ) with the lowest value 7 and highest 19.
Family support shows that the value (mean $=13.86, \mathrm{SD}=2.89$ ) with the lowest value 10 and highest 22. Social support shows that the value (mean $=12.01, \mathrm{SD}=$ 2.96) with the lowest value 8 and the highest 20. Social capital shows that the value (mean=11.9, $\mathrm{SD}=3.08$ ) with the lowest value of 7 and highest 18. Quality of life indicates that the value $($ mean $=59.82, \mathrm{SD}=8.26)$ with the lowest value of 45 and the highest 81 .

Table 2. Univariate analysis (continuous data)

\begin{tabular}{llllll}
\hline Variable & n & Mean & SD & Min. & Max. \\
\hline Income & 200 & 14.1 & 5.4 & 7.5 & 29 \\
Body Mass Index & 200 & 22.3 & 3.6 & 16.1 & 28.3 \\
Physical Activity & 200 & 10.1 & 4.1 & 4 & 21 \\
Locus of control & 200 & 12.1 & 2.9 & 7 & 19 \\
Family Support & 200 & 13.9 & 2.9 & 10 & 22 \\
Social Support & 200 & 12.0 & 2.9 & 8 & 20 \\
Social Capital & 200 & 11.9 & 3.1 & 7 & 18 \\
Quality of Life & 200 & 59.8 & 8.2 & 45 & 81 \\
\hline
\end{tabular}

Table 3. Univariate analysis (dichotomous)

\begin{tabular}{lcc}
\multicolumn{1}{c}{ Variable } & Frequency (n) & Percentage (\%) \\
\hline $\begin{array}{l}\text { Education } \\
\text { <Primary school }\end{array}$ & 111 & $55 \cdot 50$ \\
$\geq$ Primary school & 89 & 44.50 \\
Income & 112 & 61.00 \\
<minimum wage & 78 & 39.00 \\
$\geq$ minimum wage & & \\
Marital status & 101 & 50.50 \\
Single/divorced & 99 & 49.50 \\
Married & & \\
BMI & 98 & 49.00 \\
<18 and $\geq 25$ & 102 & 52.00 \\
18-25 & & \\
Physical activities & 109 & 54.50 \\
Passive & 91 & 45.50 \\
Active & & 46.00 \\
Locus of control & 92 & 54.00 \\
External & 108 & \\
Internal & & 56.00 \\
Family support & 112 & 44.00 \\
Weak & 88 & 48.00 \\
Strong & & 52.00 \\
Social support & 96 & 49.50 \\
Weak & 104 & 50.50 \\
Strong & & \\
Social Capital & 99 & \\
Ligh & 101 &
\end{tabular}


Kumalasari et al./ The ecological effect of village and biopsychosocial factors

\author{
Quality of Life \\ Poor \\ Good
}

117

58.50

83

41.50

Based on Table 3 presents univariate analysis data (dichotomous data) from 200 elderly obtained that most of those who did not graduate from elementary school were 111 people (55.50\%) and 89 people (44.50\%) had more than elementary school education. Elderly with income of $<$ minimum wage as many as 112 people (61.00\%) and 78 people (39.00\%) earn $\geq$ minimum wage. Elderly who are still single or divorced are 101 (50.50\%) and 99 are still married (49.50\%).

Elderly BMI of 98 people (49.00\%) are not normal this is either thin or fat and 102 people (52.00\%) elderly have normal BMI. Most of the elderly have less active/inactive physical activity as many as 109 people (54.50\%) and 91 people (45.50\%) active.

\section{Bivariate Analysis}

The bivariate analysis in this study aims to explain the relationship of one independent variable to one dependent variable. The variables in this study are income, education, marriage, BMI, physical activity, locus of control, family support, social support, social capital, and quality of life. The analytical test used in the bivariate analysis is the chi square test with a 95\% confidence level.

Table 4 shows that education $(\mathrm{OR}=$ 20.72; $\mathrm{p}<0.001)$, income $(\mathrm{OR}=24.78 ; \mathrm{p}$ $<0.001)$, marriage ( $\mathrm{OR}=4.30 ; \mathrm{p}<0.001)$, $\mathrm{BMI}(\mathrm{OR}=7.81 ; \mathrm{p}<0.001)$, locus of control $(\mathrm{OR}=8.72 ; \mathrm{p}<0.001)$, physical activity $(\mathrm{OR}=$ 11.22; $\mathrm{p}<0.001)$, family support $(\mathrm{OR}=6.08$; $\mathrm{p}<0.001)$, social support $(\mathrm{OR}=34.51$; $\mathrm{p}<0.001)$, and social capital $(\mathrm{OR}=6.54$; $\mathrm{p}<0001)$ increased quality of life of elderly.

Table 4. Bivariate analysis of bio psychosocial factors on the quality of life in elderly

\begin{tabular}{|c|c|c|c|c|c|c|c|c|}
\hline \multirow{3}{*}{$\begin{array}{c}\text { Independent } \\
\text { Variable }\end{array}$} & \multicolumn{4}{|c|}{ Quality of Life } & \multirow{2}{*}{\multicolumn{2}{|c|}{ Total }} & \multirow{3}{*}{ OR } & \multirow{3}{*}{$\mathbf{p}$} \\
\hline & \multicolumn{2}{|c|}{ Poor } & \multicolumn{2}{|c|}{ Good } & & & & \\
\hline & $\mathbf{n}$ & \% & $\mathbf{n}$ & $\%$ & $\mathbf{n}$ & \% & & \\
\hline \multicolumn{9}{|l|}{ Education } \\
\hline$<\mathrm{PS}$ & 96 & 86.49 & 15 & 13.51 & 111 & 100.00 & 20.72 & $<0.001$ \\
\hline$\geq \mathrm{PS}$ & 21 & 23.60 & 68 & 76.40 & 89 & 100.00 & & \\
\hline \multicolumn{9}{|l|}{ Income } \\
\hline$<$ minimum wage & 103 & 84.43 & 19 & $15 \cdot 57$ & 122 & 100.00 & 24.78 & $<0.001$ \\
\hline$\geq$ minimum wage & 14 & 17.95 & 64 & 82.05 & 78 & 100.00 & & \\
\hline \multicolumn{9}{|l|}{ Marital Status } \\
\hline Single/divorced & 76 & 75.25 & 25 & 24.75 & 101 & 100.00 & $4 \cdot 30$ & $<0.001$ \\
\hline Married & 41 & 41.41 & 58 & 58.59 & 99 & 100.00 & & \\
\hline \multicolumn{9}{|l|}{ BMI } \\
\hline Not normal & 80 & 81.63 & 18 & 18.37 & 98 & 100.00 & 7.81 & $<0.001$ \\
\hline Normal & 37 & 36.27 & 65 & 63.73 & 102 & 100.00 & & \\
\hline \multicolumn{9}{|l|}{ Locus of Control } \\
\hline External & 77 & 83.70 & 15 & 16.30 & 92 & 100.00 & 8.72 & $<0.001$ \\
\hline Internal & 40 & 37.04 & 68 & 62.96 & 108 & 100.00 & & \\
\hline \multicolumn{9}{|l|}{ Physical Activities } \\
\hline Passive & 90 & 82.57 & 19 & 17.43 & 109 & 100.00 & 11.22 & $<0.001$ \\
\hline Active & 27 & 29.67 & 64 & 70.33 & 91 & 100.00 & & \\
\hline \multicolumn{9}{|l|}{ Family Support } \\
\hline Poor & 86 & 76.79 & 26 & 23.21 & 112 & 100.00 & 6.08 & $<0.001$ \\
\hline Good & 31 & 35.23 & 57 & 64.77 & 88 & 100.00 & & \\
\hline
\end{tabular}




\begin{tabular}{lcccccccc} 
Social Support & 89 & 92.71 & 7 & 7.29 & 98 & & & \\
Poor & 28 & 26.92 & 76 & 73.08 & 104 & 100.00 & 34.51 & $<0.001$ \\
Good & 89 & 92.71 & 7 & 7.29 & 96 & 100.00 & & \\
Social Capital & & & & & & & & \\
Poor & 79 & 79.80 & 20 & 20.20 & 99 & 100.00 & 6.54 & $<0.001$ \\
Good & 38 & 37.62 & 63 & 62.38 & 101 & 100.00 & & \\
\hline
\end{tabular}

\section{Multivariate Analysis}

Multivariate analysis was used to describe the effect of more than one independent variables (income, education, marriage, BMI, physical activity, locus of control, family support, social support, and social capital) simultaneously on the dependent variable (quality of life).

There is a relationship between education and the quality of life of the elderly. Elderly with education $\geq$ elementary school or higher have a logodd for good quality of life 2.72 units higher than the elderly who are educated < elementary school.

There is a relationship between income and quality of life for the elderly. Elderly with income $\geq$ minimum wage have a logodd for good quality of life 2.90 units higher than elderly with income $<$ minimum wage.

There is a relationship between marital status and the quality of life of the elderly. Elderly with married status have logodd (likely) for good quality of life 2.37 units higher than elderly people who are divorced or not married.

Table 5. Results of multilevel logistic regression test analysis of the bio psychosocial and contextual effects of urban villages on the quality of life of the elderly

\begin{tabular}{lllll}
\hline \multicolumn{1}{c}{ Independent variables } & \multirow{2}{*}{$\begin{array}{c}\text { Regression } \\
\text { Coef. (b) }\end{array}$} & \multicolumn{2}{c}{$\mathbf{9 5 \%}$ CI } & \multirow{2}{*}{ p } \\
Fixed Effect & & & & \\
Education ( $\geq$ elementary school) & 2.72 & 0.17 & 5.26 & 0.036 \\
Income ( $\geq$ Rp 1,800,000) & 2.90 & 0.71 & 5.10 & 0.010 \\
Marital status (married) & 2.37 & 0.13 & 4.62 & 0.038 \\
BMI (18.5 -25) & 4.01 & 1.50 & 6.53 & 0.002 \\
Physical activity (good) & 2.26 & 0.33 & 4.20 & 0.022 \\
Locus of control (internal) & 2.69 & 0.41 & 4.98 & 0.021 \\
Family support (good) & 2.88 & 0.48 & 5.28 & 0.018 \\
Social support (strong) & 2.28 & 0.02 & 4.55 & 0.048 \\
Social support (strong) & 2.30 & 0.11 & 4.51 & 0.040 \\
Constanta & -13.80 & -20.63 & -6.97 & $<0.001$ \\
Random Effect & & & & \\
Village & & & & \\
Var (Constanta) & 2.24 & 0.31 & & \\
Log likelihood= -75.85 & & & & \\
LR test vs. logistic regression p= 0.033 & & & & \\
ICC=40.52\% & & & & \\
\hline
\end{tabular}


There is a relationship between BMI and the quality of life of the elderly. Elderly with normal BMI have logodd for good quality of life 4.01 units higher than elderly who have abnormal BMI.

There is a relationship between physical activity and the quality of life of the elderly. Elderly with good physical activity has a logodd for good quality of life 2.26 units higher than the elderly with less physical activity

There is a relationship between locus of control and the quality of life of the elderly. Elderly with internal locus of control have a logodd for good quality of life 2.69 units higher than the elderly with external locus of control.

There is a relationship between family support and the quality of life of the elderly. Elderly with strong family support has a logodd for good quality of life 2.88 units higher than elderly with weak family support.

There is a relationship between social support and the quality of life of the elderly. Elderly with strong social support has a logodd for good quality of life 2.28 units higher than elderly with weak social support.

There is a relationship between social capital and the quality of life of the elderly. The elderly with good social capital have a logodd for good quality of life 2.30 units higher than the elderly with low social capital.

ICC $40.52 \%$ shows that $40.52 \%$ of the variation in the quality of life of the elderly is determined by variables located at the village (kelurahan) level. This figure is greater than the role of thumb 8-10\%, so the contextual influence of the kelurahan shown from multilevel analysis is very important to note. A value of $\mathrm{p}<0.001$ indicates that there is a statistically significant difference between the models without taking into account contextual influences.

\section{DISCUSSION}

1. The influence of marital status on the quality of life of the elderly

The results of this study indicate that there is a positive influence on marital status on the quality of life of the elderly. Elderly with married status have logodd for good quality of life 2.37 units higher than unmarried elderly.

Improved quality of life for elderly people who are still married, one of which is caused by the care or attention given by their partners. A study in Khonkean, Thailand, shows that partner support affects the quality of life of the elderly, although it has not been studied that both have the same quality of life (Yodmai et al., 2018).

The elderly who have a partner are positively related to the quality of life score in the subscale of physical function, social function, vitality and mental health (Hajian-tilaki et al., 2017). The elderly life partner who is always beside him, makes the elderly have friends to talk, friends to share and complain about happiness and sadness, so that with positive coping and positive support from the couple will improve the quality of life of the elderly.

\section{The effect of education on the qua- lity of life of the elderly}

The results of this study indicate that there is a positive influence between the levels of education on the quality of life of the elderly. Elderly with education $\geq$ Elementary school or higher have a logodd for good quality of life 2.72 units higher than the elderly who are educated <elementary school.

The results of this study are in line with Onunkwor et al. (2016) in Kuala Lumpur, Malaysia showing that people with higher levels of education are more likely to engage in healthy behaviors that can improve physical health compared to those who have lower levels of education. Previous studies have also reported significantly better quality of life among people with higher levels of edu- 
cation compared to those with lower levels of education (Onunkwor et al., 2016).

The results of this study are supported by Saejong et al. (2017) in the Korean community showing that people with high education have greater ability to monitor themselves and manage responses that arise from the outside. Education is considered an important factor as a determinant of vulnerability in the elderly (Saejong et al., 2017).

\section{The effect of income on the quality of life of the elderly}

The results of this study indicate that there is a positive influence between incomes on the quality of life of the elderly. Elderly with income $\geq$ minimum wage has a logodd for good quality of life 2.90 units higher than the elderly who earn $<$ minimum wage.

Income is the amount of a person's income every month. Income as a measure of prosperity that has been achieved by someone so that it is a dominant enough factor to influence one's decision on meeting the needs of life. Significant effects of education are demonstrated by Cao et al. (2016) in the Chinese community. The study revealed that inadequate monthly income can lead to depression that will affect the quality of life of the elderly.

The quality of life of the elderly is a complex component that covers life expectancy, life satisfaction, psychological and mental health, cognitive function, health and physical function, income, living conditions, social support and social networks. Sufficient income makes the elderly feel useful in their old age and does not make the elderly feel vulnerable easily (Saejong et al., 2017).

\section{The effect of physical activity on the quality of life of the elderly}

The results of this study indicate that there is a positive influence between physical activity on the quality of life of the elderly. Elderly with good physical activity has a logodd for good quality of life 2.26 units higher than the elderly with less physical activity.

Physical activity provides an important role in improving the quality of life among the elderly and improving the health of aging. Good physical activity can improve functional performance (Abdelbasset et al., 2019).

The participant group with high activity has a higher quality of life score. This result shows a positive correlation. A similar result was reported by Medhi et al in 2019 in India that the decline in daily physical activity in the elderly not only had a negative impact on physical well-being but also the social, emotional, and mental well-being of the elderly (Medhi et al., 2019).

A study conducted in Mexico also shows that a higher level of physical activity is associated with a better quality of life. Physical inactivity is the $4^{\text {th }}$, preventable cause of noncommunicable diseases that kill 40 million people each year, equivalent to $70 \%$ of all deaths globally (Gallegos-Carrillo et al., 2019). The same thing was expressed by study conducted in the Netherlands that combining higher physical activity with higher total protein intake is associated with better quality of life, stressing the need for higher total protein intake along with active lifestyles in the elderly (Haaf et al., 2018).

\section{The Effect of BMI on the quality of life of the elderly}

The results of this study indicate that there is a positive influence between BMI on the quality of life of the elderly. Elderly with normal BMI have logodd for good quality of life 4.01 units higher than elderly who have abnormal BMI.

Decreased nutritional status in the elderly is caused by decreased physical condition or bodily functions both anatomically and functionally. Changes in body structure and function experienced by the elderly occur in almost all body systems, such as the nervous system, respiratory, endocrine, cardiovascular, and musculoskeletal ability. 
One change in structure and function occurs in the gastrointestinal system. The nutritional status of the elderly is generally influenced by food intake, lack of knowledge of the importance of good nutrition. For the elderly, meeting the nutritional needs that are given properly can help in the process of adapting or adjusting to the changes they experience (Ghimire et al., 2018).

A study in Brazil conducted by Damião et al (2018) showed a significant relationship between nutritional risk and several quality of life domains in the elderly, especially physical and psychological health, environmental quality, sensory abilities, and social participation. Nutritional status affects the quality of life indirectly through a decrease in physical function that occurs in the elderly. Poor or more nutritional status can result in limitations in elderly activities so that it is related to the quality of life of the elderly in the domain of physical health and social relations.

\section{The Effect of locus of control on the quality of life of the elderly}

The results of this study indicate that there is a positive influence between locus of control on the quality of life of the elderly. Elderly with internal locus of control have a logodd for good quality of life 2.69 units higher than elderly with external locus of control.

Control has a positive relationship with health conditions. When an individual is able to determine or influence what will happen to him then that individual is called in control. locus of control can indicate the extent to which individuals can control themselves. So that individuals who have internal control in themselves will improve healthy behavior as well as quality of life.

Individuals with a strong external locus of control orientation feel that they have limited control in their own life situations. A stronger external locus of control orientation is negatively associated with the quality of life of the elderly (Hanevold et al., 2016).
Ogbeide in Nigeria found that individuals with an internal locus of control orientation are happier. The correlation analysis results show that the orientation of the external locus of control does not show a signifycant positive relationship with life satisfaction compared to the orientation of the internal locus of control which shows a very significant positive relationship with life satisfaction (Ogbeide, 2017).

\section{The effect of family support on the quality of life of the elderly}

The results of this study indicate that there is a positive influence between the locus of control on the quality of life of the elderly. Elderly with good family support has a logodd for good quality of life 2.88 units higher than elderly with low family support.

This is in line with a study by KyuungSook who revealed that improving the quality of life of the elderly needs to be supported by the presence of family support because the attention and support provided can improve the health of the elderly (Kyung-Sook, 2017). Quality of life is related to health where an individual's satisfaction throughout his life affects them or is affected by health. Some of the elderly live with their families, their children and grandchildren.

Families who interact and help one another get support. Humans as social beings will be involved in a relationship of dependency. This is a form of support for each other. Support that occurs can be either positive or negative. Positive support will motivate in a good direction, but negative support will adversely affect. The elderly who live with families get all four components of family support with different intensities. The main cause of low family support is poor family economic conditions. Family support is needed for the elderly throughout their lives because life satisfaction comes from feeling calm and comfortable (Suwarni et al., 2018). 


\section{The effect of social support on the quality of life of the elderly}

The results of this study indicate that there is a positive influence between locus of control on the quality of life of the elderly. Elderly with good social support has a logodd for good quality of life 2.28 units higher than elderly with low social support.

One of the factors that influence the quality of life of the elderly is social support Social support is the existence of other people who can be relied upon to provide assistance, enthusiasm, acceptance, and attention, so as to improve the welfare or quality of life for the individual concerned. This social support is very important in improving the quality of life of the elderly, especially for the elderly who no longer live with their families. Psychological stresses such as depression or anxiety and stress are effectively reduced with the help of social support. Even if social support cannot eliminate stressful situations, this allows older people to be more optimistic. Therefore, social support helps older people overcome difficult situations, create new solutions and reduce their despair (Patra et al., 2017).

Kang et al. (2018) also mentioned a reciprocal relationship between social support and quality of life. Elderly with good social support will not feel lonely and depressed.

\section{The effect of social capital on the quality of life of the elderly}

The results of this study indicate that there is a positive influence between social capitals on the quality of life of the elderly. Elderly with good social capital has a logodd for good quality of life 2.30 units higher than elderly with low social capital.

Social capital is a characteristic of a community or resource that includes social organization, citizen participation, norms of reciprocity, mutual trust between community members, which facilitates cooperation to achieve mutual benefits in the development of social determinants of health. Social capital is positively related to self-reported health and daily living activity (ADL). Individuals who live in communities with high levels of social capital report themselves healthier than individuals who choose to live in communities with low levels of social capital (Kadarwati et al., 2017).

Social capital is widely recognized as a determinant of health and well-being in the environment. In environments with stronger social cohesion (cognitive aspects of social capital) or greater population participation in groups and organizations (structural aspects of social capital), the elderly feel their quality of life is higher. The association of environmental social capital and quality of life is strong when considered in differences in the characteristics of the parents themselves (Lane et al., 2019).

\section{Contextual effect of village on the quality of life of the elderly}

Village has intra-class correlation (ICC)= $40.52 \%$, this value is an indicator that the village has a contextual influence on variations in quality of life. The ICC results are greater than the standard size (rule of thumb) of multilevel analysis, so the strata describing posyandu activities need to be considered. The value of the likelihood ratio is 0.033 , which means that it is statistically significant and there are differences between the models without taking into account the contextual influence and the model that takes into account the contextual influence of the village as the second level.

The eco-social health model explains that the factors that influence the health status of individuals or communities and the distribution of health in a population are divided into several levels which can be largely modified. Based on this eco-social determinant model, it can be concluded that the health behavior of individuals, groups and communities is very closely related to the 
socioeconomic conditions, physical environment, behavior and lifestyle of individuals. The close relationship provides a holistic and systemic picture including bio psychosocial aspects and interacting factors at various levels. In addition, the presence of macro policy also supports the improvement of environmental conditions at the macro level (Murti, 2018).

\section{AUTHOR CONTRIBUTION}

Dwi Tour Kumalasari as the main author plays a role in coordinating study, conducting all stages of the study, and completing the draft. Bhisma Murti and Vitri Widyaningsih had a role in did data analysis and interpreting the results of analysis.

\section{CONFLICT OF INTEREST}

There is no conflict of interest in this study.

FUNDING AND SPONSORSHIP

This study is self-funded.

\section{ACKNOWLEDGEMENT}

We thank the Research and Development Board, the Regional Development Planning Agency, and the Health Office for allowing this study to be carried out. We also thank the elderly and cadres who participated and were willing to become respondents in the study.

\section{REFERENCE}

Cao W, Guo C, Ping W, Tan Z, Guo Y (2016). A community-based study of quality of life and depression among older adults. Int J Environ Res Public Health. 13(7): 693. https://doi.org/10.3390/ijerph13070693.

Damião R., Meneguci J, Santos, ÁDAS, Matijasevich A, Menezes PR (2018). Nutritional risk and quality of life in community-dwelling elderly: A crosssectional study. J Nutr Health Aging. 22(1): 111-116. https://doi.org/10.10- 07/s12603-017-0935-y.

Gallegos-carrillo K, Honorato-cabañas Y, Macías N (2019). Preventive health services and physical activity improve health-related quality of life in Mexican older adults. Salud Pública de México. 61(2): 106. https://doi.org/10.21149/9400.

Ghimire S, Baral BK, Pokhrel BR, Pokhrel A, Acharya A, Amatya D (2018). Depression, malnutrition, and health related quality of life among Nepali older patients. BMC Geriatrics. 18(1): 1-15. https://doi.org/10.1186/s12877-018o881-5.

Giandalia A, Russo G, Piano FLo, Elia G, Ruffo MC, Forte F, Cucinotta D (2019). Multidimensional assessment of quality of life and locus of control in elderly patients with type 2 diabetes: role of gender. APMB | Medical and Biological Sciences. 107(1). https://doi.org/10.6092/18286550/APMB.107.1.2019.OS2.

Haaf DSM, Dongen EJI, Van, Nuijten MAH (2018). Protein intake and distribution in relation to physical functioning and quality of life in community-dwelling elderly people. Nutrients. 10(4): 1-13. https://doi.org/10.3390/nu10040506.

Hajian-tilaki K, Heidari B, Hajian-tilaki A. (2017). Health related quality of life and its socio-demographic determinants among iranian elderly people: a population based cross-sectional study. Tabriz university of medical sciences. 6(1): 39-47. https://doi.org/10.15171/jcs.2017.005.

Hanevold G, Corazzini K, Selbæk G (2016). Are coping strategies and locus of control orientation associated with health-related quality of life in older adults with and without depression? Archives of Gerontology and Geriatrics. 64: 130-137. https://doi.org/10.1016- 
Kumalasari et al./ The ecological effect of village and biopsychosocial factors

/j.archger.2016.01.014.

Hanim, Agustina E (2007). Pemberdayaan kelompok lanjut usia miskin melalui usaha kredit kecil sebagai upaya ketida ktergantungan bank plecit di pasar tradisional Kota Surakarta (Empowerment of the Poor Elderly Group through Small Credit Businesses as a Dependent Effort of Bank Plecit in Surakarta Traditional Market). Laporan Penelitian (Tidak Dipublikasikan). Surakarta.

Kadarwati, Soemanto RB, Murti B (2017). The influence of family support, social capital, self-efficacy, education, employment, income, and residential status on the quality of life among the elderly in Salatiga, Central Java. J Public Health. 2(1): 58-69. https://doi.org/10.26911/jepublichealth.2017.02.01.06.

Kang H, Park M, Poock J, Hernandez W (2018). The impact of perceived social support, loneliness, and physical activity on quality of life in South Korean older adults. j.jshs. 7(2): 237-244. https://doi.org/10.1016/j.jshs.2016.05.003.

Kyung-Sook K (2017). Effects of the health status and health behavior on healthrelated quality of life of the elderly living alone and living with their families: using data from the 2014 community health survey. J Korean Acad Community Health Nurs. 28(1): 78-87. https://doi.org/10.12799/jkachn.2017.28.1.78.

Lane AP, Wong CH, Mo Š, Song S (2019). Association of neighborhood social capital with quality of life among older people in Singapore. Journal of Aging and Health. 1-20. https://doi.org/10.1177/o898264319857990.

Li H, Ji Y, Chen T (2014). The roles of different sources of social support on emotional well-being among Chinese elderly. 9(3): 1-8. https://doi.org/10.1371/journal.pone.0090051.

Medhi GK, Sarma J, Pala S, Bhattacharya H, Bora PJ, Visi V (2019). Association between health related quality of life (HRQOL) and activity of daily living (ADL) among elderly in an urban setting of Assam. India. J Family Med Prim Care. 8(5): 1760-1764. https://doi.org/10.4103\%2Fjfmpc.jfmpc_270_19.

Muckenhuber J, Fernandez K, Burkert NT, Großscha'dl F, Freidl W, Sky ER (2014). Trends in inequalities in health, risk and preventive behaviour among the advanced-age population in Austria: 1983-2007.9(5): e97400. https://doi.org/10.1371/journal.pone.0097400.

Murti B (2018). Teori Promosi dan Perilaku Kesehatan. Surakarta: Universitas Sebelas Maret.

Ogbeide ODE (2017). Effects of locus of control orientation, financial status and marital quality on life satisfaction among local government retirees In South-East Nigeria. Online Journal of Arts, Management and Social Sciences. 2(2): 99-112.

Onunkwor OF, Al-Dubai SAR, George PP, Arokiasamy J, Yadav H, Barua A, Shuaibu HO (2016). A cross-sectional study on quality of life among the elderly in non-governmental organizations' elderly homes in Kuala Lumpur. Health and Quality of Life Outcomes. 14(1): 1-10. https://doi.org/10.1186/s12955-016-0408-8.

Patra P, Alikari V, Fradelos EC, Sachlas A, Kourakos M, Paola A, Zyga S (2017). Assessment of depression in elderly. Is perceived social support related? A nursing home study depression and social support in elderly. Advances in Experimental Medicine and Biology. https://doi.org/10.1007/978-3-319-57379-3. 
Kumalasari et al./ The ecological effect of village and biopsychosocial factors

Saejong HK, Park PS, Woo Y, Lee BCC, Yeom JS (2017). The significance of frailty in the relationship between socioeconomic status and health-related quality of life in the korean community-dwelling elderly population: Mediation analysis with bootstrapping. Quality of Life Research. 26(12): 3323-3330. https://doi.org/10.1007/s11136-017-1672-8.

Setiyorini E, Wulandari NA, Sari Y, Kartika (2018). Upaya untuk meningkatkan kualitas hidup lansia melalui perlahat (persatuan lansia ingin hidup sehat) di Kelurahan Jatidowo Kecamatan Rejotangan Kabupaten Tulungagung (Efforts to improve the quality of life of the elderly through perlahat (unity of the elderly want to live healthy) in Jatidowo Village Rejotangan District Tulungagung Regency). Journal UNUSA. 2(2): 354. Retrieved from http://journal2.unusa.ac.id/index.php/CDJ/article/view /652/553.

Silviliyana M, Maylasari I, Agustina R, Karuniawati DR, Rini S, Linda A, Rosmala DFW (2018). Statistik penduduk lanjut usia (Elderly population statistics.). Badan Pusat Statistik.

Sulaeman E, Murti B, Waryana W (2015b). Peran kepemimpinan, modal sosial, ak- ses informasi serta petugas dan fasilitator kesehatan dalam pemberdayaan masyarakat bidang kesehatan (The role of leadership, social capital, access to information and health officers and facilitators in community health empowerment). Jurnal Kesehatan Masyarakat Nasional. 9(4): 353-361. http://dx.doi.org/10.21109/kesmas.v9i4.749.g472.

Suwarni S, Soemanto RB, Sudiyanto A (2018). Effect of dementia, family support, peer support, type of residence, and marital status on quality of life of the elderly in Surakarta, Central Java. J Public Health. 3(1): 83-94. Retrieved from https://doi.org/10.26911/jepublichealth.2018.03.01.07.

United Nations (2017). World aging population 2017. United Nations New York. Retrieved from https://doi.org/10.1049/el:20000788.

Yodmai K, Somrongthong R, Kumar R (2018). Determinants of quality of life among rural elderly population in Khonkean Province of Thailand. J Liaquat Uni Med Health Sci. 17(03): 180184. Retrieved from https://doi.org/10.22442/jlumhs.181730574. 